\title{
Growth Performance, Survival Rate and Nutrient Profile of Clarias Gariepinus Fingerlings Fed Rations of Soybean as Alternative Protein Source
}

\section{Olele Nkeonyeasua Florence Onyema Mcdonald I be}

\author{
Fisheries Department, Delta State University, Asaba Campus ,Nigeria
}

Odiko, Andress Edowaye

Fisheries Department, University of Benin, Benin City, Edo State, Nigeria

\section{Doi:10.5901/ ajis.2013.v2n10p193}

\begin{abstract}
The need to augment fish production from the wild has necessitated increased attention in aquaculture. Such culture encourage the use of cheap and readily available feed which brings about increased size and high yield. Fishmeal was substituted (100\%, 65\%, 35\%, 0\%) with soybean (0\%, 35\%, 65\% 100\%) in Clarias gariepinus diet. One hundred and sixty fingerlings having mean body weight of approximately $10 \mathrm{~g}$ each, were distributed into eight concrete tanks measuring $1 \times 1 \times 1.5 \mathrm{~m}$ at the rate of twenty fingerlings/tank and fed albitium. Analysis of variance revealed that the highest value for final mean body weight $(71.5 \mathrm{~g})$, specific growth rate (2.3) and Protein Efficiency Ratios (1.48), were observed in diet 3. Glutamic acid was the major amino acid with the highest concentration $(1.5 \mathrm{~g})$ in diet 2. There was a decreasing level of Lysine and Methionine with increasing levels of soy bean inclusion, at various treatments. The study has shown that when 35\% fishmeal was substituted with 65\% soybean, fish yield was not only at its highest production, but was also nutritionally beneficial.
\end{abstract}

Keywords: Growth performance, survival rate, nutrient profile, Clarias gariepinus, fingerlings

\section{Introduction}

As the need to augment fish production from the wild heightens due to increasing demand for fish, there is increased global attention on aquaculture (Owodeinde et al., 2010). According to El-Saidy and Gaber (2003); Siddhuraju and Becker (2003); Wu et al., (2004), aquaculture has become the fastest-growing food production sector in which fish meal is a primary protein source in fish diets. In aquaculture, feeding of culture fish is one of the most important factors that must be considered. Fish like other animals have a requirement for essential nutrients in order to grow properly. Nutrient requirements for fish encompasses proteins, lipids, carbohydrates, vitamins and minerals. Protein being a major constituent in fish diet, presumes that a knowledge of its requirement for fish species was essential for the formulation of a balanced diet. Johnston (2004) reported that fishmeal has always been the commonest and most popular source of protein for commercial fish feed production. However, the high cost incurred in the use of fishmeal as raw material has necessitated researches into the use of plants protein in feed formulation. Among the plant protein sources considered in aquaculture diets, soybean meal is the most widely used ingredient. It was used for the replacement of fish meal at various rations due to their high-protein content and relatively well-balanced amino acid profile, (Koumi et al., 2009). Furthermore, it has 
the advantage of being resistant to oxidation and spoilage and is naturally free from organisms such as fungi, viruses, and bacteria that are harmful to shrimp and fish (Storebakken et al., 2000).

The use of soybean meal as substitute for fishmeal in diets of many fish and marine crustaceans cannot be overemphasized (Davis and Arnold, 2000; Webster and Lim, 2002). This is because the replacement of fish protein with soya protein has not only improved growth but also reduced the cost of fish production. This assertion is in corroboration with those of El Saidy and Gaber, (2002); Wilson et al.,( 2004), who reported considerable success after the partial replacement of fish meal with soybean meal in the diet of Oreochromis niloticus. Apparent crude protein digestibility of soybean meal by trout, carp and red sea bream was 90-93\% (Yamamoto et al., 2000). Again, Chou et al., (2001) reported that incorporating soy protein in cobia (Rachycentron canadum) diets at a modest level of (11.5\%) was successful. In a similar study, (Fagbenro and Davies, 2001) reported that the results obtained indicated that $50 \%$ of fish meal protein in practical catfish diets was replaced with soybean flour.

However, some challenges exist in using soybean as fishmeal substitute in fish diets. This is because it contains some anti nutritional factors that are known to affect growth and health of the fish (Storebakken et al., 2000) and (Hendricks, 2002). For instance, in Atlantic salmon and rainbow trout, soybean meal was found to cause distinct morphological alterations in the intestine. In addition to impaired growth and protein utilization, the effects escalated with increasing dietary levels (Krogdahl and Bakke-McKellep, 2001). Dietary soybean meal also appear to stimulate immune responses because of inflammation in the distal intestine of some fish species (Krogdahl et al., 2000). However, the concentration of these anti nutrients can be reduced by proper heat processing.

In response to the rising need for more research into fish nutrition that will utilize locally available ingredients without reducing the quality of fish feed, the study was undertaken to establish the optimum replacement ration of fishmeal with soybean meal in the diet of Clarias gariepinus, it will ascertain the survival rate, growth response, and overall performance of Clarias gariepinus fed rations of soybean as well as determine the composition and concentration of Amino and fatty acid present in the carcass of fingerlings receiving various treatments.

\section{Materials and Methods}

\subsection{Study Area}

This study was conducted in the experimental tank unit of the Department of Fisheries, University of Benin for a period of twelve (12) weeks, June to August, 2012.

\subsection{Tank Preparation And Experimental Set Up}

The experimental set up consists of eight concrete tanks whose dimension was $1 \times 1 \times 1.5 \mathrm{~m}$. After the tank was checked for leakage, it was thoroughly washed to ensure the removal of dead algae and other organisms that may adversely affect water quality. Water was appropriately impounded into the tanks.

\subsection{Experimental Fish}

Good stock fingerlings were purchased from NIKSEG fish farms in Benin City. One hundred and sixty (160) fingerlings of Clarias gariepinus were randomly selected and distributed into the tanks at the rate of 20 fingerlings per tank. Forty-eight hour period was allowed for acclimatization of the fingerlings. The initial weight of the fingerlings were taken after acclimatization, before feeding commenced. They were fed to apparent satisfaction (ad-libitum) twice daily at $9.00 \mathrm{am}$ and 4.00 $\mathrm{pm}$. The weights of the fingerlings were taken bi-weekly all through the 12 week culture period. 


\subsection{Experimental Diets}

Four iso-nitrogenous diets comprising of 35\% dietary protein levels were formulated. The major source of protein in diet 1, (control) was fishmeal. The fishmeal protein was substituted at a rate of $35 \%, 65 \%$, and $100 \%$ with soybean meal in diets 2, 3 and 4, respectively. Synthetic methionine and lysine were added to the $4^{\text {th }}$ diet at the rate of $0.2 \mathrm{~kg}$ each in order to make up for their deficiency in that diet. Individual weights of the ingredients were arrived at by Pearson square method. These ingredients were then milled, mixed, produced into pellets and stored in a cool dry place according to Bolorunduro, (2002). The ingredients used and their relative contributions by weight in the diet is shown in Table 1.

Table 1: Relative weight of ingredients used in feed formulations (\% FM/SBM)

\begin{tabular}{lcccc}
\hline & Diet 1 & Diet 2 & Diet 3 & Diet 4 \\
\hline Ingredients & $100 / 0$ & $65 / 35$ & $35 / 65$ & $0 / 100$ \\
\hline Fish Meal & 50.68 & 29.63 & 15.02 & 0 \\
\hline Soy bean Meal & 0 & 16.93 & 27.08 & 31.30 \\
\hline Corn Meal & 21.41 & 23.47 & 26.20 & 30.10 \\
\hline Wheat Offal & 21.41 & 23.47 & 26.20 & 30.10 \\
\hline Bone Meal & 1.5 & 1.5 & 1.5 & 1.5 \\
\hline Palm Oil & 1.5 & 1.5 & 1.5 & 1.5 \\
\hline Vitamin Premix & 2.0 & 2.0 & 2.0 & 2.0 \\
\hline Lysine & 0 & 0 & 0 & 1.0 \\
\hline Methionine & 0 & 0 & 0 & 1.0 \\
\hline Starch & 1.5 & 1.5 & 1.5 & 1.5 \\
\hline Total & 100 & 100 & 100 & 100 \\
\hline
\end{tabular}

FM: Fish meal and SBM: Soybean meal

\subsection{Amino Acid Analysis}

\subsubsection{Defatting}

About $2.0 \mathrm{~g}$ of each ingredient was weighed into the extraction thimble and the fat extracted with chloroform/methanol mixture using a soxhlet extraction apparatus (AOAC, 2003). The extraction lasted for 5 to 6 hours.

\subsubsection{Hydrolysis of sample}

Between 30 to $35 \mathrm{mg}$ of each defatted sample was weighed into glass ampoule, $7 \mathrm{ml}$ of $6 \mathrm{~N} \mathrm{HCl}$ was added and air was expelled by passing nitrogen into the ampoule in order to avoid possible oxidation of some amino acids during hydrolysis. The glass ampoule was sealed with Bunsen flame and put in an oven at $150 \pm 5^{\circ} \mathrm{C}$ for 22 hours. The ampoule was allowed to cool before the content was filtered. The filtrate was evaporated to dryness at $40^{\circ} \mathrm{C}$ under vacuum in a rotary evaporator. The residue was dissolved with $5 \mathrm{~cm}^{3}$ of acetate buffer and stored in a plastic specimen bottle which was kept in a deep freezer.

\subsubsection{Sample analysis}

The method of analysis used was Ion-Exchange Chromatography (IEC) (FAO/WHO, 1991). The amount loaded for each of the samples was between 5 to $10 \mu \mathrm{l}$. This was dispensed into the cartridge of the analyzer designed to separate and analyze free acid, neutral acid, basic acid, and 
amino acid of the hydrolysates. The period of analysis lasted 76 minutes for each sample. The liquid flow rate in the column was $0.5 \mathrm{~cm} 3 / \mathrm{min}$ and the column temperature was maintained at $60^{\circ} \mathrm{C}$. It has reproducibility consistence within $\pm 3 \%$.

\subsubsection{Lipid Extraction and Fatty Acid Analysis}

Lipid determination was carried out using the modified Bligh and Dyer procedure (AOAC, 2003). Methanol and chloroform were used as solvents at the ratio of $1: 1$. The fatty acids were converted to their methyl esters and heptanes. Internal standards were employed for estimation of actual fatty acids in the fat. Identification and quantification of fatty acids was carried out by gas chromatography according to (AOAC, 2003).

\subsection{Water Quality Parameters}

Water quality was closely monitored to ensure a suitable environment for the fishes. Parameters measured and recorded include Temperature, Transparency, Dissolved oxygen and Hydrogen-ionConcentration $(\mathrm{pH})$.

Temperature: This was measured in-situ with the aid of mercury in glass thermometer. The measurement was taken morning and evening

Dissolved Oxygen: This was measured bi-weekly using the Winkler's method as proposed by (APHA 2002) 840)

Hydrogen-Ion- Concentration (pH): This was measured with a $\mathrm{pH}$ metre (Schott-Gerate CG

Transparency: This was measured daily and recorded with the aid of a Secchi Disc, following the procedure proposed by (Swann, 2006)

Apart from water quality parameters such as temperature and transparency that were measured in-situ, every other water quality parameter was analyzed at SPLENDID RESEARCH LABORATORIES, at Kilometer 9, Ugbowo, Lagos Road, opposite Eddy Grace Petrol Station, Isihor, Benin-City, Edo State, Nigeria.

\subsection{Growth Parameters}

Determination of parameters such as Specific Growth Rate (SGR), Survival Rate (SR), Food Conversion Ratio (FCR), and Protein Efficiency Ratio (PER), were conducted according to De Silva and Anderson (1995). Parameters measured include

- Initial body weight of the fingerlings before feeding commenced.

- Final body weight of the fingerlings at the end of the experiment.

- Total weight gained = Final body weight $(\mathrm{kg})$ - Initial body weight $(\mathrm{kg})$

- Mean weight gained per fingerling $(\mathrm{g})=$ Total Weight Gain

- $\quad$ Specific Growth Rate $=\underline{\log W f-\log W i} \times 100$

Time

Where $\mathrm{Wf}=$ Final body weight at time $(\mathrm{T})$

Wi $=$ Initial body weight at time $(T)$

- Food Conversion Ratio (FCR) = Feed consumed Body weight gained

- Protein Efficiency Ratio (PER) = Fish weight gain Protein Fed

- Initial mean length of fingerlings before commencement of feeding

- Final mean length of fingerlings 
- Mean daily length gain = Final mean length-Initial mean length

Time

Proximate analysis of fish carcass at harvest was carried out using the procedure in AOAC (2003).

\subsection{Statistical Analysis}

The experiment was completely randomized with replicates. Means and standard deviations $( \pm S D /$ range) were computed. Significance of variations in the growth parameters were tested with one way analysis of variance, ANOVA, while means were separated with the Duncan Multiple Range Test.

\section{Results}

\subsection{Some Water Quality Parameters}

Water quality parameters recorded during the study revealed that they were maintained at optimal levels conducive for the ideal culture of fingerlings. Temperature data, ranged between $27-28^{\circ} \mathrm{C}$ while dissolved oxygen levels, ranged between 5.67 to $6.17 \mathrm{mg} / \mathrm{l}$, Table 2 .

Table 2: Mean values for water quality parameters recorded during the culture period

\begin{tabular}{lcccccc}
\hline \multicolumn{1}{c}{ Parameters } & Wk2 & Wk4 & Wk6 & Wk8 & Wk10 & Wk12 \\
\hline Temperature ${ }^{0} \mathrm{C}$ & 28 & 27 & 27.6 & 27 & 27 & 28 \\
Transparency $(\mathrm{cm})$ & 38 & 42 & 42 & 38 & 40 & 36 \\
Dissolved Oxygen $(\mathrm{mg} / \mathrm{l})$ & 6.04 & 5.67 & 6.17 & 6.08 & 6 & 6.14 \\
$\mathrm{PH}$ & 6.90 & 6.83 & 6.34 & 6.82 & 6.7 & 6.88 \\
\hline
\end{tabular}

\subsection{Growth Parameters}

le 3, shows the initial body weight per fingerlings, which were about the same at the beginning of the experiment. Final body weight on the other hand showed significant differences between treatments. For instance, fingerlings fed diet 3 recorded the highest final mean body weight $71.5 \mathrm{~g}$, followed by diet 2 with a record of $68.75 \mathrm{~g}$ while the least value $(52.5 \mathrm{~g})$ was recorded in fingerlings fed on diet 1, which incidentally was the control treatment. In terms of Food Conversion Ratio (FCR), the highest value (7.13) was recorded in fingerlings belonging to diet 1 , while diet 3 recorded the least value (4.93).

Table 3: ANOVA data on growth response of fingerlings fed soybean substituted diets (FM/SBM).

\begin{tabular}{lccccc}
\hline \multicolumn{1}{c}{ Parameters } & Diet1 100/0 & Diet2 65/35 & Diet3 35/65 & Diet4 0/100 & SEM \\
\hline Initial mean body weight(g) & $10^{\mathrm{a}}$ & $10^{\mathrm{a}}$ & $10^{\mathrm{a}}$ & $10^{\mathrm{a}}$ & 0.27 \\
Final mean body weight(g) & $52.5^{\mathrm{d}}$ & $68.75^{\mathrm{b}}$ & $71.5^{\mathrm{a}}$ & $66^{\mathrm{c}}$ & 1.26 \\
Weight gain(g) & $42.5^{\mathrm{d}}$ & $58.75^{\mathrm{b}}$ & $61.5^{\mathrm{a}}$ & $56^{\mathrm{c}}$ & 1.260 \\
\% Weight gain & $425^{\mathrm{d}}$ & $587.5^{\mathrm{b}}$ & $615^{\mathrm{a}}$ & $560^{\mathrm{c}}$ & 12.60 \\
Specific Growth Rate(SGR) & $1.9^{\mathrm{c}}$ & $2.3^{\mathrm{a}}$ & $2.3^{\mathrm{a}}$ & $2.2^{\mathrm{b}}$ & 0.04 \\
Food Conversion Ratio(FCR) & $7.13^{\mathrm{a}}$ & $5.16^{\mathrm{c}}$ & $4.93^{\mathrm{d}}$ & $6.47^{\mathrm{b}}$ & 0.13 \\
Protein Efficiency Ratio(PER) & $1.02^{\mathrm{d}}$ & $1.41^{\mathrm{b}}$ & $1.48^{\mathrm{a}}$ & $1.34^{\mathrm{c}}$ & 0.11 \\
Initial Mean Length(cm) & $9^{\mathrm{a}}$ & $9^{\mathrm{a}}$ & $9^{\mathrm{a}}$ & $9^{\mathrm{a}}$ & 0.17 \\
Final Mean Length $(\mathrm{cm})$ & $21.3^{\mathrm{d}}$ & $23.3^{\mathrm{b}}$ & $45.2^{\mathrm{a}}$ & $22.2^{\mathrm{c}}$ & 0.97 \\
Mean Length Gain(cm) & $12.3^{\mathrm{c}}$ & $14.3^{\mathrm{b}}$ & $36.2^{\mathrm{a}}$ & $13.2^{\mathrm{c}}$ & 0.97 \\
*MDLG (cm/d) & $0.25^{\mathrm{c}}$ & $0.28^{\mathrm{b}}$ & $0.54^{\mathrm{a}}$ & $0.26^{\mathrm{c}}$ & 0.01
\end{tabular}




$\begin{array}{llllll}\text { Survival rate }(\%) & 82.5^{\mathrm{a}} & 82.5^{\mathrm{a}} & 82.5^{\mathrm{a}} & 80.5^{\mathrm{a}} & 4.07\end{array}$

*MDLG=Mean Daily Length Gain $(\mathrm{cm} / \mathrm{d})$. Means with the same alphabet on the horizontal rows are not significantly different at $(p>0.05)$

\subsection{Proximate Composition Of Fingerlings}

ANOVA analysis on proximate composition of fingerlings fed various diets is shown in Table 4 . The table revealed that the highest crude protein value (60.12) was recorded in fingerlings fed on diet 2 . This was closely followed by those fed diet 3 which recorded 60.09 while fingerlings fed on diet 4 had the least crude protein composition 59.88. Moisture content was found to be highest in fingerlings placed on diet 4 which recorded a value of 12.96 , while fingerlings fed on diet 3 recorded the least value 12.63 , Table 4.

Table 4: Mean composition of fingerlings fed soybean substituted diets

\begin{tabular}{ccccccc}
\hline Diets & FM/SBM & Crude Protein & Fat & Ash & Fiber & Moisture Content \\
\hline D1 & $100 / 0$ & $59.98^{\mathrm{c}}$ & $19.22^{\mathrm{b}}$ & $3.36^{\mathrm{c}}$ & $1.09^{\mathrm{b}}$ & $12.88^{\mathrm{b}}$ \\
D2 & $65 / 35$ & $60.12^{\mathrm{a}}$ & $19.18^{\mathrm{c}}$ & $3.44^{\mathrm{b}}$ & $1.04^{\mathrm{c}}$ & $12.75^{\mathrm{c}}$ \\
D3 & $35 / 65$ & $60.09^{\mathrm{b}}$ & $19.35^{\mathrm{a}}$ & $3.52^{\mathrm{a}}$ & $1.09^{\mathrm{b}}$ & $12.63^{\mathrm{d}}$ \\
D4 & $0 / 100$ & $59.88^{\mathrm{d}}$ & $19.13^{\mathrm{d}}$ & $3.29^{\mathrm{d}}$ & $1.12^{\mathrm{a}}$ & $12.96^{\mathrm{a}}$ \\
SEM & & 0.009 & 0.009 & 0.009 & 0.009 & 0.008 \\
\hline
\end{tabular}

Means with the same alphabet on the vertical column are not significantly different at $(p>0.05)$

\subsection{Amino Acid Composition}

ANOVA data for amino acid composition of the fingerlings is shown in Table 5. The table revealed that diet 2 recorded the highest value 0.82 in Alanine content. It was followed closely by diet 3 which had a value of 0.78 , with diet 4 recording the least value 0.76 . Also diet 4 recorded the highest lysine concentration of $0.93 \mathrm{~g}$ while diet 1 recorded the lowest value 0.76 . Methionine composition was highest in fingerlings fed diet 4 which had a value of $(0.54)$, followed by fingerlings fed on diets 2 and 3 which recorded values of $(0.49$ and 0.42$)$ respectively. Fingerlings placed on diet 1 , recorded the least value $(0.38)$.

Table 5. ANOVA data on amino acid composition of fingerlings fed soybean substituted (FM/SBM) diet.

\begin{tabular}{lccccc}
\hline Amino Acid & $100 / 0$ & $65 / 35$ & $35 / 65$ & $0 / 100$ & SEM \\
\hline Aspattic & $1.29^{\mathrm{b}}$ & $1.33^{\mathrm{a}}$ & $1.25^{\mathrm{c}}$ & $1.28^{\mathrm{b}}$ & 0.02 \\
Glutamic & $1.45^{\mathrm{a}}$ & $1.5^{\mathrm{a}}$ & $1.44^{\mathrm{a}}$ & $1.29^{\mathrm{b}}$ & 0.03 \\
Arginin & $0.83^{\mathrm{a}}$ & $0.81^{\mathrm{a}}$ & $0.76^{\mathrm{b}}$ & $0.75^{\mathrm{b}}$ & 0.01 \\
Lysine & $0.76^{\mathrm{d}}$ & $0.89^{\mathrm{b}}$ & $0.8^{\mathrm{c}}$ & $0.93^{\mathrm{a}}$ & 0.01 \\
Methionine & $0.38^{\mathrm{d}}$ & $0.49^{\mathrm{b}}$ & $0.42^{\mathrm{c}}$ & $0.54^{\mathrm{a}}$ & 0.01 \\
Phenylalanine & $0.67^{\mathrm{b}}$ & $0.72^{\mathrm{a}}$ & $0.69^{\mathrm{b}}$ & $0.62^{\mathrm{c}}$ & 0.01 \\
Threonine & $0.60^{\mathrm{a}}$ & $0.53^{\mathrm{b}}$ & $0.49^{\mathrm{c}}$ & $0.47^{\mathrm{c}}$ & 0.03 \\
Valine & $0.93^{\mathrm{a}}$ & $0.91^{\mathrm{b}}$ & $0.92^{\mathrm{a}}$ & $0.89^{\mathrm{c}}$ & 0.01 \\
Seriine & $0.69^{\mathrm{b}}$ & $0.87^{\mathrm{a}}$ & $0.64^{\mathrm{c}}$ & $0.62^{\mathrm{d}}$ & 0.01 \\
Proline & $0.55^{\mathrm{a}}$ & $0.53^{\mathrm{a}}$ & $0.52^{\mathrm{a}}$ & $0.51^{\mathrm{b}}$ & 0.01 \\
Leucine & $1.29^{\mathrm{a}}$ & $1.22^{\mathrm{a}}$ & $1.24^{\mathrm{a}}$ & $1.2^{\mathrm{a}}$ & 0.03 \\
Triptophan & $0.16^{\mathrm{b}}$ & $0.18^{\mathrm{a}}$ & $0.14^{\mathrm{c}}$ & $0.15^{\mathrm{c}}$ & 0.01 \\
Histidine & $0.33^{\mathrm{a}}$ & $0.27^{\mathrm{c}}$ & $0.29^{\mathrm{b}}$ & $0.25^{\mathrm{d}}$ & 0.01 \\
Glycine & $0.48^{\mathrm{a}}$ & $0.46^{\mathrm{b}}$ & $0.42^{\mathrm{d}}$ & $0.44^{\mathrm{c}}$ & 0.01 \\
& & 198 & & &
\end{tabular}




\begin{tabular}{|c|c|c|c|c|c|}
\hline & $0.80^{\mathrm{a}}$ & $0.82^{\mathrm{a}}$ & $0.78^{b}$ & $0.76^{c}$ & 0.0 \\
\hline & $0.60^{\mathrm{a}}$ & $0.62^{\mathrm{a}}$ & $0.42^{b}$ & $0.45^{b}$ & \\
\hline
\end{tabular}

Means with the same alphabet on the horizontal rows are not significantly different at $(p>0.05)$ $\mathrm{FM}=$ Fishmeal and SBM= Soy bean Meal.

\subsection{Fatty Acid Composition}

Analysis of variance for fatty acid composition of fingerlings fed various diets is shown in Table 6 . It revealed that fingerlings fed diet 2 had the highest concentration of linoleic acid $(25.69 \mathrm{~g})$, closely followed by those fed diet 1 which recorded a value of $25.55 \mathrm{~g}$. Fingerlings on diet 3 recorded the least value: $23.63 \mathrm{~g}$. In terms of Palmitic acid, diet 1 had the highest concentration: $26.18 \mathrm{~g}$ while the least concentration was recorded for diet 4 which had a value of $25.38 \mathrm{~g}$.

Table 6: ANOVA data on fatty acid composition of fingerlings fed rations of soybean substituted $\operatorname{diet}(\mathrm{FM} / \mathrm{SBM})$

\begin{tabular}{lccccc}
\multicolumn{1}{c}{ Fatty Acid } & $100 / 0$ & $65 / 35$ & $35 / 65$ & $0 / 100$ & SEM \\
\hline Palmitic (C16.0) & $26.18^{\mathrm{a}}$ & $25.96^{\mathrm{b}}$ & $25.44^{\mathrm{c}}$ & $25.38^{\mathrm{d}}$ & 0.009 \\
Stearic (C 18.0) & $15.33^{\mathrm{a}}$ & $15.20^{\mathrm{b}}$ & $15.39^{\mathrm{a}}$ & $15.37^{\mathrm{a}}$ & 0.029 \\
Oleic (C 18.1) & $16.22^{\mathrm{d}}$ & $16.55^{\mathrm{b}}$ & $16.85^{\mathrm{a}}$ & $16.36^{\mathrm{c}}$ & 0.009 \\
Linoleic (C 18.2) & $25.55^{\mathrm{b}}$ & $25.69^{\mathrm{a}}$ & $23.63^{\mathrm{d}}$ & $24.18^{\mathrm{c}}$ & 0.005 \\
Linolenic (C 18.3) & $12.66^{\mathrm{a}}$ & $12.48^{\mathrm{b}}$ & $12.18^{\mathrm{d}}$ & $12.36^{\mathrm{c}}$ & 0.009 \\
Behenic (C22.0) & $2.66^{\mathrm{a}}$ & $2.35^{\mathrm{b}}$ & $2.29^{\mathrm{c}}$ & $2.34^{\mathrm{b}}$ & 0.009 \\
\hline
\end{tabular}

Means with the same alphabet on the horizontal rows are not significantly different at $(p>0.05)$

\section{Discussion}

\subsection{Water Quality Parameters}

Water quality parameters were maintained within acceptable ranges for aqua-cultural practice according to Swann (2006).

\subsection{Growth Parameters}

Table 3 indicated that soybean inclusion in diets of Clarias gariepinus fingerlings resulted in better body weight gain, growth rate, and protein conversion efficiency. Data in Table 3 also show that Clarias gariepinus fingerlings performed better, when fed diet in which $65 \%$ fishmeal was replaced with $35 \%$ soybean meal. This value exceeds that obtained by (Fagbenro and Davies, 2001) where only $50 \%$ fishmeal was replaced by $35 \%$ soybean flour for catfish diet. It is however not surprising to note that the fingerlings placed on diet 4 (100\% soybean meal) did better than those fed diet 1 (100\% Fishmeal). For instance, while fingerlings placed on diet 1 recorded a final weight and mean weight gain of $52.5 \mathrm{~g}$ and $42.5 \mathrm{~g}$ respectively, those placed on diet 4 recorded $66 \mathrm{~g}$ and $56 \mathrm{~g}$ for the same parameters. This superior performance, could be attributed to the supplemental Essential Amino Acids (lysine and methionine) that was added in the $4^{\text {th }}$ diet. This further lends credence to the submissions of Chang et al., (2003) who demonstrated that supplementing plant protein with lysine and methionine in low protein diet was beneficial for catfish growth and performance. The lower food conversion ratio of 4.93, recorded by fingerlings fed Diet 3 is an indication that it is of better quality than the other diets. According to Ugwumba and Ugwumba, 2007), lower food conversion ratio indicate higher protein conversion efficiency which results in 
better growth. Survival rate amongst the treatments was not significantly different. The mortalities recorded could be attributed to handling stress as the mortalities were usually recorded after the occasional sampling of fingerlings.

\subsection{Proximate Composition Of Fingerlings}

The crude protein content of fingerlings fed different diets show that diets 2 and 3 recorded relatively high values $(60.12 \%$ and $60.09 \%)$ respectively. Treatments 1 and 4 also recorded close values of $(59.98 \%$ and $59.88 \%)$ respectively. These values agree with those reported by Abolude and Abdullahi (2005) on proximate and mineral contents of Clarias gariepinus. High values of protein recorded during the study especially with the inclusion of soybean at different levels in the diets, indicate that the fingerlings were reliable sources of good quality protein for man.

Fat content of fingerlings, for all treatments was above $5 \%$, hence Clarias gariepinus can be described as a fatty fish (Tocher et al., 2008). However, fat content of fish was highest in fishes fed diet containing $65 \%$ soy protein and $35 \%$ fishmeal and which recorded a value of $19.35 \%$ in Table 4. Moisture content of fingerlings were not only relatively high but statistically significant in all treatments. This observation agrees with that reported by (Adefemi, 2011) who stated that such moisture content enables fish become more susceptible to deterioration if kept unpreserved for long after harvest. Crude Fiber composition of the diets ranged between $1.04 \mathrm{~g}$ to $1.09 \mathrm{~g}$ and showed no particular trend relative to increasing levels of soy protein composition.

\subsection{Amino Acid Composition}

The data in Table 5 indicate that Glutamic acid whose values ranged from $1.29 \mathrm{~g}$ to $1.5 \mathrm{~g}$ had the highest concentration among the amino acid profile. Diet 2 recorded the highest value of $1.5 \mathrm{~g}$. This observation is in agreement with similar studies conducted by (Adeyeye and Adamu, 2003). The table also revealed that lysine and Methionine compositions increased with increasing levels of soybean inclusion in the diet, as a result of their inclusion in the diet. Chou et al., (2001), are of the opinion that lysine and Methionine are the limiting amino acids in most plant protein sources. Threonine, which is also an essential amino acid component, slightly decreased with increasing levels of soybean inclusion. This is a clear indication of its essentiality as it cannot be efficiently synthesized in the body of the fish (Yamamoto et al., 2000). The decrease in Threonine level could be as a result of its insufficiency in the soy bean meal. However, irrespective of the soybean inclusion level, Clarias gariepinus remains a good source of Essential Amino Acids (EAA) as the values recorded were within the range recommended by FAO/WHO, (1991)

\subsection{Fatty Acid Composition}

Fatty acid profile of fingerlings undergoing the various treatments showed that Palmitic acid is the predominant saturated fatty acid. This observation lends credence to the views of Osibona et al., (2006) who conducted a similar study on the proximate and fatty acid composition of C. gariepinus. There was a noticeable decrease in palmitic acid concentration with an increasing level of soybean inclusion in the diets. Table 6 revealed that fingerlings fed diet 1 had the highest palmitic acid concentration level of $26.18 \mathrm{~g}$, with diets 2,3 and 4 recording $25.96 \mathrm{~g}, 25.44 \mathrm{~g}$, and $25.38 \mathrm{~g}$ respectively. This trend however does not agree with the views of Osibona et al., (2006) who opined that palmitic acid is a key metabolite in fish whose level is not affected by diet. Oleic acid, which is the major monounsaturated fatty acid in the fingerlings under study, showed no trend, relative to soybean inclusion. This fatty acid according to Osibona et al., (2006) is of exogenous origin and subject to the types of feed consumed by fish. The Poly-Unsaturated Fatty Acids (PUFA) present in the fingerlings include linoleic and linolenic acid. Linolenic acid which as an omega-3 fatty acid, has a range of $23.6 \mathrm{~g}$ to $25.69 \mathrm{~g}$ making it the next major fatty acid in the fish, after 
palmitic acid. It is well-known that essential $\omega$-3 fatty acids has beneficial effect on human health, primarily in prevention and healing of cardiovascular diseases, and are important factors in neurological development (Arts, 2001). The fatty acid composition of fingerlings in the present study, imply that it contains the basic quantity required by man.

\section{Conclusion and Recommendation}

The use of a readily available, economically viable plant protein source, enhance the economic sustainability of aquaculture. It is also very important that such protein source should contain very low anti-nutrients, good amino acid profile and various supplements to improve nutritional balance and palatability of the feed. Soy protein has without doubt, met these requirements. Although the present study did not look into the economics of production, however based on the ease of cultivation and low cost of procuring soybean meal in comparison to fishmeal, it could be recommended that farmers utilize soybean to partially replace fishmeal up to $65 \%$ in fish diet. This will enable the farmer cut down on cost of production without compromising the quality of the fish.

\section{References}

Abolude D.S, Abdulahhi S.A (2005). Proximate and mineral contents in component parts of Clarias garipenus and Synodontis schall from Zaria, Nigeria. Nigeria Food Journal, vol 23, pp. 1-7.

Adefemi O.S (2011). Chemical composition of Tilapia mosambis fish from major dams in Ekiti-State Nigeria. African Journal of Food Science vol. 5, no10, pp. 550-554.

Adeyeye E.I, Adamu A.S (2003). Chemical composition and food properties of Gmynarchus niloticus. Bios Biotechnological Resources, Asia, vol 3, no 2 pp. 265-272.

AOAC (Association of Official Analytical Chemist) (2003). Official methods of analysis. $17^{\text {th }}$ ed. Washington DC, USA.

APHA (2002). Standard methods for the examination of Water and Wastewater 20th Edition. American Public Health Association, Washington Dc USA

Arts M.T, Ackman R.G, Holub B.J (2001). Essential fatty acids in aquatic ecosystems: a crucial link between diet and human health and evolution. Canadian Journal of Fisheries Aquatic Science, vol 58, pp. 122-137.

Bolorunduro P.I (2002). Feed formulation and feeding practices in Fish Culture. Fisheries Extension Bulletin vol 152, Fisheries series No.2, pp. 28

Booth M.A, Allan G.L and Warner-Smith R (2000). Effects of grinding, steam conditioning and extrusion of a practical diet on digestibility and weight gain of silver perch, Bidyanus bidyanus. Aquaculture, vol 182, pp 287-299.

Chang, Z. J., Hardy, R.W. and Usry, J. L. (2003). Plant protein ingredients with lysine supplements. Aquaculture, vol 213, pp. 553-565.

Chou R.L, Su M.S, Chen H.Y (2001). Optimal dietary protein and lipid levels for juvenile cobia (Rachycentron canadum) Aquaculture, vol 193 (2001), pp. 81-89.

Davis, D.A. and Arnold, C.R. (2000). Replacement of fishmeal in practical diets for the Pacific white shrimp, Litopenaeus vannamei. Aquaculture, vol 185, pp. 291-298.

EL-Saidy D.M.S, Gaber M.M.A (2002). Complete replacement of fishmeal by soybean with the dietary Llysine supplementation in Nile tilapia fingerlings. Journal of World Aquaculture Society. vol 33, pp. 297-309.

EL-Saidy D.M.S, Gaber M.M.A (2003). Replacement of fish meal with a mixture of different plant protein sources in juvenile Nile tilapia (Oreochromis niloticus (L.) diets. Aquaculture Research, vol 34, pp. 1119-1127.

Fagbenro, O. A. and Davies S. J. (2001). Use of soybean flour (dehulled, solvent-extracted soybean) as a fish meal substitute in practical diets for African catfish, Clarias gariepinus (Burchell 1822): growth, feed utilization and digestibility. Aquaculture Nutrition vol 12, pp. 128-132.

FAO/WHO (1991). Protein quality evaluation (Report of joint FAO/WHO) expert consultation. (FAO food and nutrition paper 51). Rome, Italy. 
Hendricks J.D (2002). Adventitious toxins J.E. Halver, R.W. Hardy (Eds.), Fish Nutrition (3rd ed.), Academic Press, San Diego, Carlifornia, USA, pp. 601- 649.

Indiana sea grant Program Purdue University. Retrieved from http://aquanic.org /publicat/state/il-in/as503.htm on 20th February, 2006.

J ohnston S. (2004). Fishmeal demand to outstrip supply in 2004? Fish Farmer International File Vol. 18 pp. 15.

Koumi A.R, Atse B.C and Kouame L.P (2009). Utilization of soya protein as an alternative protein source in Oreochromis niloticus diet: Growth performance, feed utilization, proximate composition and organoleptic characteristics. African Journal of Biotechnology, Vol. 8 no 1, pp. 091-097.

Krogdahl A, Bakke-McKellep A.M. Roed K., Baeverfjord G. (2000). Feeding Atlantic salmon Salmo salar L. soybean products: effects on disease resistance (furunculosis), and lysozyme and Igm levels in the intestinal mucosa. Aquaculture Nutrition, vol 6 Pp. 77-84

Krogdahl A, Bakke-McKellep., A.M, (2001). Soybean in salmonid diets: antinutrients, pathologies, immune responses and possible solutions. Book of Abstract; Aquaculture 2001, Lake Buena Vista, Florida, USA . Pp340

Osibona A.O, Kusemiju K and Akande G.R (2009). Fatty acid composition and amino acid profile of two freshwater species, african catfish (clarias gariepinus) and tilapia (tilapia zillii)Africa journal of food agriculture, nutrition and development vol 9, no1, pp. 1584-5374

Owodeinde F.G, Ndimele P.E and Anetekhai, (2011). Reproductive, Growth Performance and Nutrient Utilization of Heterobranchus bidorsalis and its Hybrid "Clariabranchus" Induced with synthetic hormone and pituitary gland of Heterobranchus bidorsalis. International journal of Zoological Research no 7, pp. 345-357.

Siddhuraju P, Becker K (2003). Comparative nutritional evaluation of differentially processed mucuna seeds [Mucuna pruriens (L.) D C. var. Utilis (Wall ex Wight) Baker ex Burck] on growth performance, feed utilization and body composition in Nile tilapia (Oreochromis niloticus L). Aquaculture Resources, 34: 487-500.

Storebakken T, Refstie S, Ruyter B (2000). Soy products as fat and protein sources in fish feeds for intensive aquaculture. J.K. Drackley (Ed.), Soy in Animal Nutrition. Animal Science Society, Savoy (2000), pp. 127-170

Swann, L. (2006). A fish farmer's guide to understanding water quality. The Illinois

Tocher D.R, Bendisken E.A, Campbell P.J, Bell J.G (2008). The role of phospholipids in nutrition and metabolism of teleost fish. Aquaculture, vol 280, pp. 21-34.

Ugwumba, A. A. and Ugwumba, O. A. (2007). Food and feeding ecology of fishes in Nigeria. Ist edition Crystal Publishers, Ajah,Lagos. ISBN: 978-062-018-4. pp 91

Webster, C.D. and Lim, C.E. (2002). Nutrient Requirements and Feeding of Finfish for Aquaculture. Canadian Aquaculture Bulletin. pp 43.

Wilson MF, Luiz EP, Margarida MB, Pezzato AC, Valéria RB (2004). Use of ideal protein concept for precision formulation of amino acid levels in fish meal free diets for juvenile Nile tilapia (Oreochromis niloticus.) Aquaculture Resources. vol 35, pp 1110-1116.

Wu G.S, Chung Y.M, Lin W.Y, Chen H.H (2004). Effect of substituting dehulled or fermented soy bean meal for fish meal in diets on growth of hybrid tilapia, Oreochromis niloticus $\times 0$. aureus. Journal of Fish Society Taiwan. vol 30, pp 291-297.

Yamamoto, T., A. Akimoto, S. Kishi, T. Unuma and T. Akiyama. (2000). Apparent and true digestibilities of amino acids from several protein sources for fingerling rainbow trout, common carp and red sea bream. Fisheries Science, vol 64, no3, 448-458. 